\title{
Attitudes of physicians towards the care of critically ill elderly patients - a European survey
}

\author{
B. Guidet ${ }^{1,2,3}$ (D), D. W. De Lange ${ }^{4}$, S. Christensen ${ }^{5}$, R. Moreno ${ }^{6}$, J. Fjølner ${ }^{5}$ (D), G. Dumas ${ }^{1,2}$ and \\ H. Flaatten ${ }^{7}$ \\ ${ }^{1}$ Hôpital Saint-Antoine, Service de Réanimation Médicale, Assistance Publique - Hôpitaux de Paris, Paris, France \\ ${ }^{2}$ UPMC Univ Paris 06, UMR_S 1136, Institut Pierre Louis d’Epidémiologie et de Santé Publique, Sorbonne Universités, Paris, France \\ ${ }^{3}$ UMR_S 1136, Institut Pierre Louis d'Epidémiologie et de Santé Publique, INSERM, Paris, France \\ ${ }^{4}$ Department of Intensive Care Medicine, University Medical Center, Utrecht, The Netherlands \\ ${ }^{5}$ Department of Anaesthesiology and Intensive Care, Aarhus University Hospital, Aarhus N, Denmark \\ ${ }^{6}$ Unidade de Cuidados Intensivos Neurocríticos, Hospital de São José, Centro Hospitalar de Lisboa Central, Lisbon, Portugal \\ ${ }^{7}$ Department of Clinical Medicine, University of Bergen, Department of Anaesthesia and Intensive Care, Haukeland University Hospital, Bergen, \\ Norway
}

\section{Correspondence}

B. Guidet, 184 rue du Faubourg Saint Antoine,

75012 Paris, France

E-mail: bertrand.guidet@aphp.fr

Conflicts of interest

None of the authors have any relevant conflict of interest related to this study.

Funding

No funding was received for the study.

Submitted 18 August 2017; accepted 4

October 2017; submission 16 May 2017

Citation

Guidet B, De Lange DW, Christensen S, Moreno R, Fjølner J, Dumas G, Flaatten H. Attitudes of physicians towards the care of critically ill elderly patients - a European survey. Acta Anaesthesiologica Scandinavica 2018

doi: 10.1111/aas.13021
Background: Very elderly patients are one of the fastest growing population in ICUs worldwide. There are lots of controversies regarding admission, discharge of critically ill elderly patients, and also on treatment intensity during the ICU stay. As a consequence, practices vary considerably from one ICU to another. In that perspective, we collected opinions of experienced ICU physicians across Europe on statements focusing on patients older than 80 .

Methods: We sent an online questionnaire to the coordinator ICU physician of all participating ICUs of an recent European, observational study of Very old critically Ill Patients (VIPl study). This questionnaire contained 12 statements about admission, triage, treatment and discharge of patients older than 80 .

Results: We received answers from 162 ICUs (52\% of VIPI-study) spanning 20 different European countries. There were major disagreements between ICUs. Responders disagree that: there is clear evidence that ICU admission is beneficial (37\%); seeking relatives' opinion is mandatory $(17 \%)$; written triage guidelines must be available either at the hospital or ICU level $(20 \%)$; level of care should be reduced (25\%); a consultation of a geriatrician should be sought $(34 \%)$ and a geriatrician should be part of the post-ICU trail $(11 \%)$. The percentage of disagreement varies between statements and European regions.

Conclusion: There are major differences in the attitude of European ICU physicians on the admission, triage and treatment policies of patients older than 80 emphasizing the lack of consensus and poor level of evidence for most of the statements and outlining the need for future interventional studies.

\section{Editorial comment}

Requests for ICU admission of elderly patients are increasing in Europe. The limited physiological reserves associated with old age make the benefit of ICU admission of elderly patients sometimes less certain. Here a survey among European intensivists illustrates a wide range of attitudes concerning this issue. 
Patients over 80 years account for up to $15 \%$ of all ICU admissions in western ICUs. $^{1-3}$ ICU physicians may be reluctant to admit these elderly patients and may question the benefit of ICU treatment while considering the burden for hospital and society.

As a consequence, there is a great deal of heterogeneity in admission policies of elderly patients from one country to another or within the same country and even within the same ICU. ${ }^{4,5}$ Indeed, there is a huge variation in the proportion of elderly patients that is eventually admitted to the ICU. In a recent European study $75 \%$ of elderly patients, that were considered eligible for ICU admission, were not even referred to the ICU by the emergency department physician, and of those who were referred another half was refused admission by the intensivist. ${ }^{6}$ This leads to significant disparities in the use of ICU treatment in the elderly population. ${ }^{2}$

Clear and unambiguous guidelines for the admission of elderly patients are lacking. Apparently more subjective and individual appraisal of the elderly patient still dictates admission. Aside from the acute medical problem requiring admission to intensive care, various other dimensions of the health status of elderly individuals have a major influence on their prognosis in terms of mortality or functional autonomy. ${ }^{5}$ In a recent consensus review these parameters were discussed and a number of variables associated with poor long-term outcome were identified including active cancer, cachexia, high degree of frailty, low functional status, reason for admission (medical stay and urgent surgery vs. scheduled surgery). ${ }^{2}$

Despite the fact that all these variables and parameters are associated with worse outcome in elderly ICU patients, there are limited data on how ICU physicians prioritize this evidence when considering ICU treatment of an elderly patient (admission, level of care, and discharge). The aim of this study was to probe the attitudes of the ICU coordinators towards care of the very old ICU patients (VIP) in a recent European observational study in Europe ${ }^{7}$.

\section{Methods}

The 12 questions were expressed as statements and were reviewed by an expert panel consisting of the VIPI study scientific committee and further classified in five main groups: (1) general assessment of ICU benefit for elderly patients in term of survival without detailed information on the delay after ICU admission and quality of life but apart from effective palliative care, (2) triage, (3) level of care during the ICU stay, (4) discharge policy and (5) post-ICU care.

A survey (https://www.surveymonkey.net) was made available on line for all local coordinators of VIPI participating ICUs. The survey was launched October 21th, 2016 and closed January 26th, 2017.

The responses to the statements were constructed using a Likert scale with five possible answers: strongly agree, agree, disagree, strongly disagree and no answer. It was also possible to give additional comments to each statement. We aggregated countries in five regions: North: Norway, Sweden, Denmark; West: Ireland, Great Britain; Central: Netherlands, Belgium, Germany, Austria, Switzerland; South: France, Italy, Portugal, Spain; and East: Poland, Czech Republic, Romania, Russia, Turkey, and Greece. To see whether responses were affected by the number of ICU beds in the different countries, we used the most recent available data from a study published in $2012^{8}$ and classified the countries as above or below the average number of critical care beds/100,000 inhabitants (11.5). To test whether health economy could influence the responses, we used data from Organisation for Economic Co-operation and Development (OECD) ${ }^{9}$ and classified the countries as high level when health expenditure as a share of gross domestic product was above the median of $9.3 \%$. Information on countries of respondents is available in Table $S 1$.

The results are presented as percentages. Comparison of percentage was performed with a Kruskal-Wallis test. For statistical analysis, responses strongly agree and agree were merged as well as responses for strongly disagree and disagree since the response 'strongly' might be subjective. Comparison according to responses to first question was performed with Fisher's exact test. Statistics were performed with the $\mathbf{R}$ software.

Free comments were extracted showing the most significant comments and summarized the main messages for each question (Data S1). 


\section{Results}

We received answers from 162 ICU study coordinators. Information about countries was documented for 155 questionnaires and covered 20 different European countries as displayed in Fig. 1. The number of answers was distributed between the five defined regions with North 34, West 42, Central 28, South 29 and East 22.

The responses are presented in Table 1. Most of the responders $(63 \%)$ agree that there is clear evidence that ICU admission is beneficial for the elderly and old critically ill patients; however, a significant minority (37\%) disagrees with this statement. The distribution of the responses was similar across the five regions (Table 2).

Almost all ICU responders agree that advance directives should be promoted. However, some differences between regions were observed in the level of agreement. In the Central region $64 \%$ and in West region $69 \%$ ICU physicians strongly agree with the statement compared with just $18 \%$ in East and 33\% in North regions. Concerning triage, $20 \%$ of respondents disagree that written triage guidelines must be available either at the hospital or ICU level. However, ICUs located in East Europe were more in favor of guidelines.

The attitude towards the intensity with which elderly patients should be treated once admitted to the ICU showed a high level of disagreement. We proposed a controversial statement suggesting that elderly patients should receive less intensive treatment than younger patient ('less is more') to minimize side-effects of ICU (iatrogenic events, delirium, etc.). The majority of ICU physicians (75\%) agreed that less is more' but $25 \%$ disagreed. The central and north countries were more willing to apply all

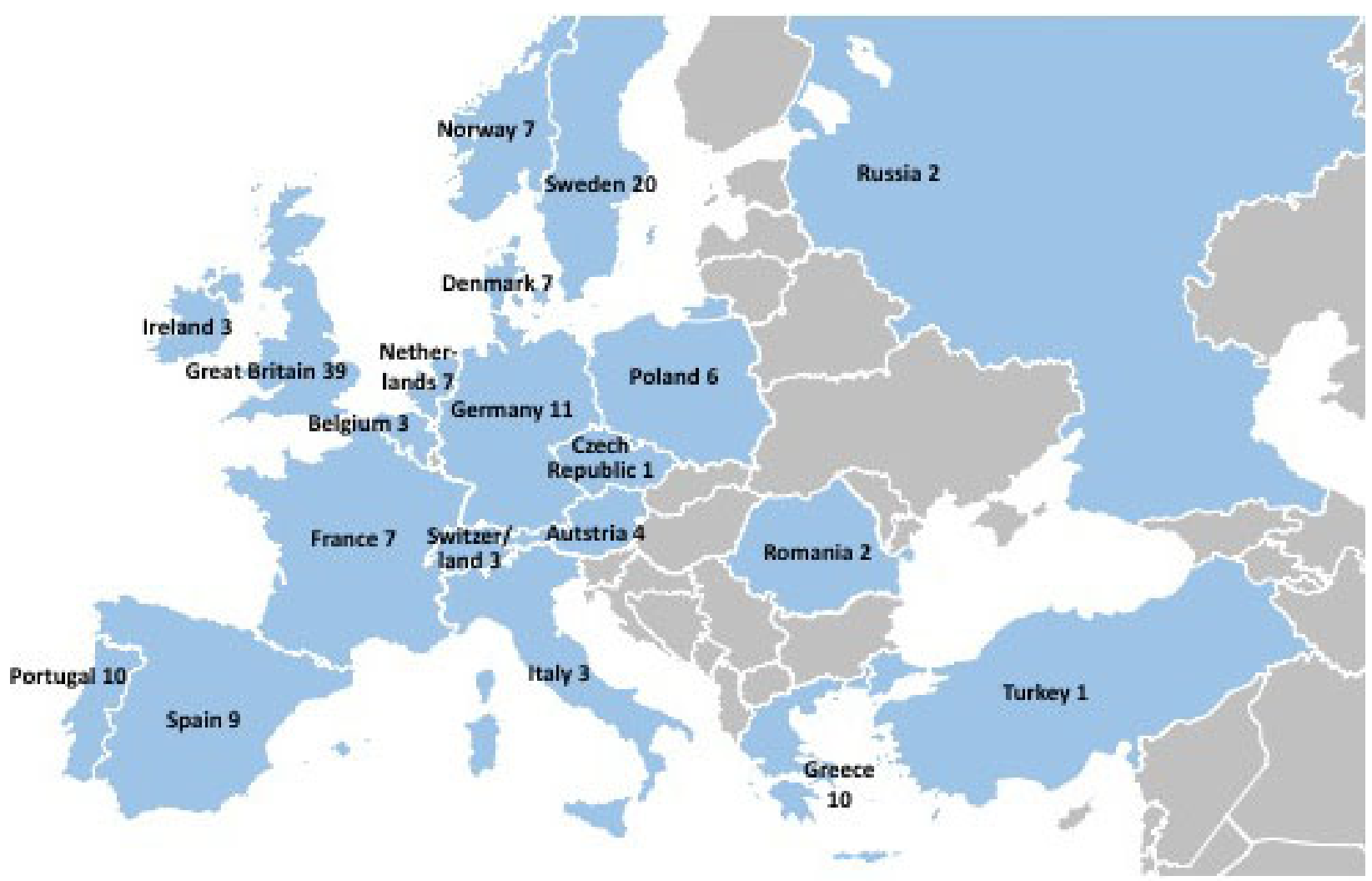

1

Fig. 1. Distribution of responses across Europe. [Colour figure can be viewed at wileyonlinelibrary.com] 


\begin{tabular}{|c|c|c|c|}
\hline & Responses & $N=162$ & $\%$ \\
\hline \multirow{5}{*}{$\begin{array}{l}\text { There is clear } \\
\text { evidence that } \\
\text { ICU admission is } \\
\text { beneficial for } \\
\text { elderly ICU } \\
\text { patients at a } \\
\text { group level }\end{array}$} & Strongly agree & 18 & 11 \\
\hline & Agree & 84 & 52 \\
\hline & Disagree & 54 & 34 \\
\hline & Strongly disagree & 5 & 3 \\
\hline & NA & 1 & \\
\hline \multirow{5}{*}{$\begin{array}{l}\text { Patients advance } \\
\text { directives should } \\
\text { be promoted at } \\
\text { any level in the } \\
\text { hospital }\end{array}$} & Strongly agree & 83 & 52 \\
\hline & Agree & 72 & 45 \\
\hline & Disagree & 4 & 2 \\
\hline & Strongly disagree & 1 & 1 \\
\hline & NA & 2 & \\
\hline \multirow{5}{*}{$\begin{array}{l}\text { If a patient is } \\
\text { unable to } \\
\text { communicate, } \\
\text { seeking for } \\
\text { relatives' opinion } \\
\text { on behalf of the } \\
\text { elderly person is } \\
\text { mandatory }\end{array}$} & Strongly agree & 58 & 36 \\
\hline & Agree & 76 & 47 \\
\hline & Disagree & 24 & 15 \\
\hline & Strongly disagree & 3 & 2 \\
\hline & NA & 1 & \\
\hline \multirow{5}{*}{$\begin{array}{l}\text { Written triage } \\
\text { guidelines must } \\
\text { be available at } \\
\text { the hospital level }\end{array}$} & Strongly agree & 35 & 23 \\
\hline & Agree & 85 & 56 \\
\hline & Disagree & 31 & 20 \\
\hline & Strongly disagree & 2 & 1 \\
\hline & NA & 9 & \\
\hline \multirow{5}{*}{$\begin{array}{l}\text { Written triage } \\
\text { guidelines must } \\
\text { be available at } \\
\text { the ICU level }\end{array}$} & Strongly agree & 39 & 25 \\
\hline & Agree & 87 & 55 \\
\hline & Disagree & 31 & 19 \\
\hline & Strongly disagree & 2 & 1 \\
\hline & NA & 3 & \\
\hline \multirow{5}{*}{$\begin{array}{l}\text { Assessment of } \\
\text { frailty should be } \\
\text { mandatory when } \\
\text { deciding to admit } \\
\text { an elderly patient } \\
\text { in ICU }\end{array}$} & Strongly agree & 72 & 45 \\
\hline & Agree & 75 & 47 \\
\hline & Disagree & 12 & 8 \\
\hline & Strongly disagree & 0 & \\
\hline & NA & 3 & \\
\hline \multirow{4}{*}{$\begin{array}{l}\text { Early goal directed } \\
\text { rehabilitation } \\
\text { programs should } \\
\text { be promoted }\end{array}$} & Strongly agree & 81 & 50 \\
\hline & Agree & 77 & 48 \\
\hline & Disagree & 4 & 2 \\
\hline & $\begin{array}{l}\text { Strongly disagree } \\
\text { NA }\end{array}$ & 0 & \\
\hline \multirow{5}{*}{$\begin{array}{l}\text { In case of } \\
\text { uncertainty } \\
\text { about the } \\
\text { condition, the } \\
\text { patient should be } \\
\text { admitted and } \\
\text { given an ICU trial }\end{array}$} & Strongly agree & 40 & 25 \\
\hline & Agree & 107 & 67 \\
\hline & Disagree & 13 & 8 \\
\hline & Strongly disagree & & \\
\hline & NA & 2 & \\
\hline
\end{tabular}

possible treatments to elderly patients without restrictions in the attitude towards the level of care.
Table 1 (Continued)

\begin{tabular}{llcr}
\hline & Responses & $N=162$ & $\%$ \\
\hline Level of care & Strongly agree & 72 & 45 \\
should be & Agree & 73 & 46 \\
systematically & Disagree & 14 & 9 \\
and collectively & Strongly disagree & 0 & \\
reassess at day 2 & NA & 3 & \\
-3 in the ICU ('in & & & \\
ICU triage') & & & \\
In particular in the & Strongly agree & 24 & 15 \\
elderly patients, & Agree & 97 & 60 \\
less is more with & Disagree & 38 & 24 \\
regards to & Strongly disagree & 2 & 1 \\
common ICU & NA & 1 & \\
procedures with & & & \\
exception of & & & \\
early mobilization & & & \\
and training & & & \\
activities & & 28 & 18 \\
The consultation & Strongly agree & 76 & 48 \\
of a geriatrician & Agree & 49 & 31 \\
should be sought & Disagree & 49 \\
whenever & Strongly disagree & 4 & 3 \\
possible & NA & 5 & \\
A geriatrician & Strongly agree & 55 & 34 \\
should be a part & Agree & 88 & 55 \\
of the post-ICU & Disagree & 16 & 10 \\
trail for survivors & Strongly disagree & 1 & 1 \\
& NA & 2 & \\
\hline
\end{tabular}

NA, not answered.

Elderly patients have specific health problems different from the general population of ICU patients. Almost all respondents agree that frailty should be assessed when deciding to admit an elderly patient in ICU. However, 34\% disagreed that a geriatrician should be consulted during the ICU stay. Conversely, there was a large agreement, 9 out of 10, that agreed that geriatric expertise plays an important role in the post-ICU care. The north region was less in favor of geriatrician implication after ICU discharge (Table 2).

As presented in Table 3, we found no major differences in the attitudes towards elderly in the ICU between those that agreed to question 1 regarding the existence of clear evidence for a beneficial effect of intensive care treatment of elderly and those who disagreed.

There was no impact of the number of beds (Table 4) while respondents working in ICUs located in countries with low Health 
Table 2 univariate comparison according country's responder

\begin{tabular}{|c|c|c|c|c|c|c|c|}
\hline & & $\begin{array}{l}\text { Central } \\
N=28\end{array}$ & $\begin{array}{l}\text { East } \\
N=22\end{array}$ & $\begin{array}{l}\text { North } \\
N=34\end{array}$ & $\begin{array}{l}\text { South } \\
N=29\end{array}$ & $\begin{array}{l}\text { West } \\
N=42\end{array}$ & $P$-value \\
\hline \multirow{5}{*}{$\begin{array}{l}\text { There is clear evidence } \\
\text { that ICU admission is } \\
\text { beneficial for elderly } \\
\text { ICU patients at a group } \\
\text { level }\end{array}$} & Strongly agree & $4(14)$ & $1(5)$ & $2(6)$ & $5(17)$ & $5(12)$ & \multirow[t]{5}{*}{0.47} \\
\hline & Agree & $13(46)$ & $13(59)$ & $17(50)$ & $17(59)$ & $19(46)$ & \\
\hline & Disagree & $10(36)$ & $8(36)$ & $14(41)$ & $6(21)$ & $15(37)$ & \\
\hline & Strongly disagree & $1(4)$ & $0(0)$ & $1(3)$ & $1(3)$ & $2(5)$ & \\
\hline & NA & 0 & 0 & 0 & 0 & 1 & \\
\hline \multirow{5}{*}{$\begin{array}{l}\text { Patients advance } \\
\text { directives should be } \\
\text { promoted at any level } \\
\text { in the hospital }\end{array}$} & Strongly agree & $18(64)$ & $4(18)$ & $11(33)$ & $17(61)$ & $29(69)$ & \multirow[t]{5}{*}{0.0001} \\
\hline & Agree & $10(36)$ & $16(73)$ & $20(61)$ & $11(39)$ & $12(29)$ & \\
\hline & Disagree & $0(0)$ & $1(5)$ & $2(6)$ & $0(0)$ & $1(2)$ & \\
\hline & Strongly disagree & $0(0)$ & $1(5)$ & $0(0)$ & $0(0)$ & $0(0)$ & \\
\hline & NA & 0 & 0 & 1 & 1 & 0 & \\
\hline \multirow{5}{*}{$\begin{array}{l}\text { If a patient is unable to } \\
\text { communicate, seeking } \\
\text { for relatives' opinion on } \\
\text { behalf of the elderly } \\
\text { person is mandatory }\end{array}$} & Strongly agree & 11 (39) & $6(27)$ & $9(26)$ & $15(54)$ & $12(29)$ & \multirow[t]{5}{*}{0.082} \\
\hline & Agree & $14(50)$ & $15(68)$ & $17(50)$ & $10(36)$ & $18(43)$ & \\
\hline & Disagree & $2(7)$ & 1 (5) & $7(21)$ & $3(11)$ & $11(26)$ & \\
\hline & Strongly disagree & $1(4)$ & $0(0)$ & $1(3)$ & $0(0)$ & $1(2)$ & \\
\hline & NA & 0 & 0 & 0 & 1 & 0 & \\
\hline \multirow{5}{*}{$\begin{array}{l}\text { Written triage guidelines } \\
\text { must be available at } \\
\text { the hospital level }\end{array}$} & Strongly agree & $6(22)$ & $11(52)$ & $6(20)$ & $5(19)$ & $6(15)$ & \multirow[t]{5}{*}{0.0024} \\
\hline & Agree & $14(52)$ & $10(48)$ & $19(63)$ & $15(56)$ & $21(51)$ & \\
\hline & Disagree & $7(26)$ & $0(0)$ & $5(17)$ & $7(26)$ & $12(29)$ & \\
\hline & Strongly disagree & $0(0)$ & $0(0)$ & $0(0)$ & $0(0)$ & $2(5)$ & \\
\hline & NA & 1 & 1 & 4 & 2 & 1 & \\
\hline \multirow{5}{*}{$\begin{array}{l}\text { Written triage guidelines } \\
\text { must be available at } \\
\text { the ICU level }\end{array}$} & Strongly agree & $7(25)$ & $9(45)$ & $9(26)$ & $6(21)$ & $5(12)$ & \multirow[t]{5}{*}{0.016} \\
\hline & Agree & $15(54)$ & $10(50)$ & $19(56)$ & $16(57)$ & $23(55)$ & \\
\hline & Disagree & $6(21)$ & $1(5)$ & $6(18)$ & $6(21)$ & $12(29)$ & \\
\hline & Strongly disagree & $0(0)$ & $0(0)$ & $0(0)$ & $0(0)$ & $2(5)$ & \\
\hline & NA & 0 & 2 & 0 & 1 & 0 & \\
\hline \multirow{5}{*}{$\begin{array}{l}\text { Assessment of frailty } \\
\text { should be mandatory } \\
\text { when deciding to admit } \\
\text { an elderly patient in } \\
\text { ICU }\end{array}$} & Strongly agree & 11 (39) & $8(36)$ & $13(41)$ & $18(62)$ & $19(46)$ & \multirow[t]{5}{*}{0.24} \\
\hline & Agree & $13(46)$ & $14(64)$ & $19(59)$ & $11(38)$ & $15(37)$ & \\
\hline & Disagree & $4(14)$ & $0(0)$ & $0(0)$ & $0(0)$ & $7(17)$ & \\
\hline & Strongly disagree & $0(0)$ & $0(0)$ & $0(0)$ & $0(0)$ & $0(0)$ & \\
\hline & NA & 0 & 0 & 2 & 0 & 1 & \\
\hline \multirow{4}{*}{$\begin{array}{l}\text { Early goal directed } \\
\text { rehabilitation programs } \\
\text { should be promoted }\end{array}$} & Strongly agree & $17(61)$ & $15(68)$ & $7(21)$ & $17(59)$ & $21(50)$ & \multirow[t]{4}{*}{0.0004} \\
\hline & Agree & 11 (39) & $7(32)$ & $23(68)$ & $12(41)$ & $21(50)$ & \\
\hline & Disagree & $0(0)$ & $0(0)$ & $4(12)$ & $0(0)$ & $0(0)$ & \\
\hline & Strongly disagree & $0(0)$ & $0(0)$ & $0(0)$ & $0(0)$ & $0(0)$ & \\
\hline \multirow{5}{*}{$\begin{array}{l}\text { In case of uncertainty } \\
\text { about the condition, } \\
\text { the patient should be } \\
\text { admitted and given an } \\
\text { ICU trial }\end{array}$} & Strongly agree & $8(29)$ & $5(24)$ & $7(21)$ & $9(31)$ & $8(19)$ & \multirow[t]{5}{*}{0.58} \\
\hline & Agree & $18(64)$ & $12(57)$ & $25(76)$ & $19(66)$ & $30(71)$ & \\
\hline & Disagree & $2(7)$ & $4(19)$ & $1(3)$ & $1(3)$ & $4(10)$ & \\
\hline & Strongly disagree & $0(0)$ & $0(0)$ & $0(0)$ & $0(0)$ & $0(0)$ & \\
\hline & NA & 0 & 1 & 1 & 0 & 0 & \\
\hline \multirow{5}{*}{$\begin{array}{l}\text { Level of care should be } \\
\text { systematically and } \\
\text { collectively reassess at } \\
\text { day 2-3 in the ICU ('in } \\
\text { ICU triage') }\end{array}$} & Strongly agree & $7(26)$ & $9(41)$ & $19(56)$ & $20(69)$ & $14(35)$ & \multirow[t]{5}{*}{0.0058} \\
\hline & Agree & $16(59)$ & $11(50)$ & $12(35)$ & $9(31)$ & $23(57)$ & \\
\hline & Disagree & $4(15)$ & $2(9)$ & $3(9)$ & $0(0)$ & $3(8)$ & \\
\hline & Strongly disagree & $0(0)$ & $0(0)$ & $0(0)$ & $0(0)$ & $0(0)$ & \\
\hline & NA & 1 & 0 & 0 & 0 & 2 & \\
\hline \multirow{5}{*}{$\begin{array}{l}\text { In particular in the } \\
\text { elderly patients, less is } \\
\text { more with regards to } \\
\text { common ICU } \\
\text { procedures with } \\
\text { exception of early } \\
\text { mobilization and } \\
\text { training activities }\end{array}$} & Strongly agree & $4(14)$ & $3(14)$ & $4(12)$ & $7(25)$ & $4(10)$ & \multirow[t]{5}{*}{0.019} \\
\hline & Agree & $14(50)$ & $18(82)$ & $16(47)$ & $18(64)$ & $27(64)$ & \\
\hline & Disagree & $9(32)$ & 1 (5) & $13(38)$ & $3(11)$ & $11(26)$ & \\
\hline & Strongly disagree & $1(4)$ & $0(0)$ & $1(3)$ & $0(0)$ & $0(0)$ & \\
\hline & NA & 0 & 0 & 0 & 1 & 0 & \\
\hline
\end{tabular}




\begin{tabular}{|c|c|c|c|c|c|c|c|}
\hline & & $\begin{array}{l}\text { Central } \\
N=28\end{array}$ & $\begin{array}{l}\text { East } \\
N=22\end{array}$ & $\begin{array}{l}\text { North } \\
N=34\end{array}$ & $\begin{array}{l}\text { South } \\
N=29\end{array}$ & $\begin{array}{l}\text { West } \\
N=42\end{array}$ & $P$-value \\
\hline \multirow{5}{*}{$\begin{array}{l}\text { The consultation of a } \\
\text { geriatrician should be } \\
\text { sought whenever } \\
\text { possible }\end{array}$} & Strongly agree & $1(4)$ & $4(20)$ & $3(9)$ & $6(21)$ & $12(29)$ & \multirow[t]{5}{*}{0.20} \\
\hline & Agree & $16(59)$ & $10(50)$ & $16(48)$ & $15(54)$ & $18(43)$ & \\
\hline & Disagree & $10(37)$ & $6(30)$ & $13(39)$ & $5(18)$ & $11(26)$ & \\
\hline & Strongly disagree & $0(0)$ & $0(0)$ & $1(3)$ & $2(7)$ & $1(2)$ & \\
\hline & NA & 1 & 2 & 1 & 1 & 0 & \\
\hline \multirow{5}{*}{$\begin{array}{l}\text { A geriatrician should be } \\
\text { a part of the post-ICU } \\
\text { trail for survivors }\end{array}$} & Strongly agree & $7(25)$ & $5(23)$ & $6(18)$ & 11 (39) & $23(55)$ & \multirow[t]{5}{*}{0.0017} \\
\hline & Agree & $18(64)$ & $14(64)$ & $20(61)$ & $15(54)$ & $18(43)$ & \\
\hline & Disagree & $3(11)$ & $3(14)$ & $6(18)$ & $2(7)$ & $1(2)$ & \\
\hline & Strongly disagree & $0(0)$ & $0(0)$ & $1(3)$ & $0(0)$ & $0(0)$ & \\
\hline & NA & 0 & 0 & 1 & 1 & 0 & \\
\hline
\end{tabular}

expenditures as a share of GDP were more in favor of ICU and hospital guidelines and treatment limitation (Table 5).

\section{Discussion}

Although not representative of European ICUs' physicians, we collected responses of 162 experienced ICU coordinators (physicians) working in 20 different European countries and with particular interest in the field of research on elderly patients since they coordinated for their own ICU the VIP prospective study. ${ }^{7}$ This survey demonstrates important differences in the perception of elderly ICU patients. There are differences in attitudes within European regions concerning triage and level of care in the ICU of very elderly patients. An important finding is the disconnection between how elderly patients should be triaged, treated, discharged and the estimation of benefit of an ICU admission. The verbatim (Data S1) emphasizes the lack of strong evidence and great uncertainties. Several physicians express their doubt and uncertainties when asked about their attitudes towards the care of critically ill elderly patients.

This field of research and medicine is highly controversial. The debate is not only ICU-centered but it also concerns other specialties within the hospital, the patient and family members, general practitioner (GPs), and various other stakeholders. There is also a societal perspective and huge uncertainties with regards to the future. How will modern countries cope with the increase in critically ill elderly patients? There are several discrepancies between the level of evidence and the response to the survey. It suggests that other factors, besides grade of evidence, are important in the decision-making process: culture, religion, financial constraints.

Are the responses to the survey in agreement with current evidence?

Very elderly critically ill patients ${ }^{1-5,10-12}$ represent a growing proportion of all ICU patients. However, not all critically ill patients over 80 years are admitted to the ICU. This implicates that physicians in general and ICU physicians in particular create an enormous admission bias. Clearly, the opinions of ICU physicians whether or not an admission is beneficial for very elderly patients influences admission policies, ${ }^{10-12}$ aggressiveness of subsequent treatment and outcome.

This is exemplified by the result to the question whether an ICU admission is considered beneficial for elderly patients. Interestingly, only $11 \%$ of respondents stated that they strongly agree that ICU admission is beneficial for elderly patients as a group while $37 \%$ strongly disagree or disagree. In other words, approximately onethird of all respondents question the level of evidence supporting ICU admission for elderly patients. As a matter of fact, ICU and in-hospital mortality is higher in elderly patients compared to younger patients. ${ }^{2,13}$ The 6 months mortality is around $50 \%$ in unselected critically ill elderly patients and recent studies have failed to 


\begin{tabular}{|c|c|c|c|c|}
\hline $\begin{array}{l}\text { ICU is beneficial for } \\
\text { elderly }\end{array}$ & & $\begin{array}{l}\text { YES } \\
N=102\end{array}$ & $\begin{array}{l}\text { NO } \\
N=59\end{array}$ & $P$-value \\
\hline $\begin{array}{l}\text { Patients advance } \\
\text { directives should be } \\
\text { promoted at any level } \\
\text { in the hospital }\end{array}$ & $\begin{array}{l}\text { Agree } \\
\text { Disagree } \\
\text { NA }\end{array}$ & $\begin{array}{l}99(98 \%) \\
2(2) \\
1\end{array}$ & $\begin{array}{l}55(95) \\
3(5) \\
1\end{array}$ & 0.36 \\
\hline $\begin{array}{l}\text { If a patient is unable to } \\
\text { communicate, seeking } \\
\text { for relatives' opinion } \\
\text { on behalf of the } \\
\text { elderly person is } \\
\text { mandatory }\end{array}$ & $\begin{array}{l}\text { Agree } \\
\text { Disagree } \\
\text { NA }\end{array}$ & $\begin{array}{l}89(88) \\
12(12) \\
1\end{array}$ & $\begin{array}{l}45(76) \\
14(24) \\
0\end{array}$ & 0.074 \\
\hline $\begin{array}{l}\text { Written triage guidelines } \\
\text { must be available at } \\
\text { the hospital level }\end{array}$ & $\begin{array}{l}\text { Agree } \\
\text { Disagree } \\
\text { NA }\end{array}$ & $\begin{array}{l}79(82) \\
17(18) \\
6\end{array}$ & $\begin{array}{l}41(73) \\
15(27) \\
3\end{array}$ & 0.22 \\
\hline $\begin{array}{l}\text { Written triage guidelines } \\
\text { must be available at } \\
\text { the ICU level }\end{array}$ & $\begin{array}{l}\text { Agree } \\
\text { Disagree } \\
\text { NA }\end{array}$ & $\begin{array}{c}82(82) \\
18(18) \\
2\end{array}$ & $\begin{array}{c}44(76) \\
14(24) \\
1\end{array}$ & 0.41 \\
\hline $\begin{array}{l}\text { Assessment of frailty } \\
\text { should be mandatory } \\
\text { when deciding to } \\
\text { admit an elderly } \\
\text { patient in ICU }\end{array}$ & $\begin{array}{l}\text { Agree } \\
\text { Disagree } \\
\text { NA }\end{array}$ & $\begin{array}{c}89(90) \\
10(10) \\
3\end{array}$ & $\begin{array}{l}58(98) \\
1(2) \\
0\end{array}$ & 0.054 \\
\hline $\begin{array}{l}\text { Early goal directed } \\
\text { rehabilitation } \\
\text { programs should be } \\
\text { promoted }\end{array}$ & $\begin{array}{l}\text { Agree } \\
\text { Disagree }\end{array}$ & $\begin{array}{c}98(96) \\
4(4)\end{array}$ & $\begin{array}{c}59(100) \\
0(0)\end{array}$ & 0.30 \\
\hline $\begin{array}{l}\text { In case of uncertainty } \\
\text { about the condition, } \\
\text { the patient should be } \\
\text { admitted and given an } \\
\text { ICU trial }\end{array}$ & $\begin{array}{l}\text { Agree } \\
\text { Disagree } \\
\text { NA }\end{array}$ & $\begin{array}{l}94(94) \\
6(6) \\
2\end{array}$ & $\begin{array}{l}53(90) \\
6(10) \\
0\end{array}$ & 0.36 \\
\hline $\begin{array}{l}\text { Level of care should be } \\
\text { systematically and } \\
\text { collectively reassess at } \\
\text { day } 2-3 \text { in the ICU ('in } \\
\text { ICU triage') }\end{array}$ & $\begin{array}{l}\text { Agree } \\
\text { Disagree } \\
\text { NA }\end{array}$ & $\begin{array}{l}90(90) \\
10(10) \\
2\end{array}$ & $\begin{array}{l}55(95) \\
3(5) \\
1\end{array}$ & 0.38 \\
\hline $\begin{array}{l}\text { In particular in the } \\
\text { elderly patients,less is } \\
\text { more with regards to } \\
\text { common ICU } \\
\text { procedures with } \\
\text { exception of early } \\
\text { mobilization and } \\
\text { training activities }\end{array}$ & $\begin{array}{l}\text { Agree } \\
\text { Disagree } \\
\text { NA }\end{array}$ & $\begin{array}{c}76(75) \\
25(25) \\
1\end{array}$ & $\begin{array}{l}45(76) \\
14(24) \\
0\end{array}$ & 1.00 \\
\hline $\begin{array}{l}\text { The consultation of a } \\
\text { geriatrician should be } \\
\text { sought whenever } \\
\text { possible }\end{array}$ & $\begin{array}{l}\text { Agree } \\
\text { Disagree } \\
\text { NA }\end{array}$ & $\begin{array}{c}62(63) \\
36(37) \\
4\end{array}$ & $\begin{array}{c}42(72) \\
16(28) \\
1\end{array}$ & 0.29 \\
\hline $\begin{array}{l}\text { A geriatrician should be } \\
\text { a part of the post-ICU } \\
\text { trail for survivors }\end{array}$ & $\begin{array}{l}\text { Agree } \\
\text { Disagree } \\
\text { NA }\end{array}$ & $\begin{array}{l}87(86) \\
14(14) \\
1\end{array}$ & $\begin{array}{l}55(95) \\
3(5) \\
1\end{array}$ & 0.11 \\
\hline
\end{tabular}

demonstrate long-term benefit of ICU admission in elderly patient. ${ }^{10,14}$

Several factors might account for this poor prognosis: poor triage process with under or over-use of ICU, inadequate treatment during the ICU stay, poor discharge policy (too early, too late, wrong destination, etc.).

There is a kind of disconnection between how elderly patients should be triaged, treated, discharged and the estimation of benefit of an ICU admission.

The triage is a multistep, multidisciplinary and collective decision. How is the patient presented to the ICU physician $?^{4,6}$ Are patient advance directives available? If the patient is unable to communicate, should we rely on relatives' opinion? Again, there is a lack of consensus among ICU physicians if the triage process is a corner stone of elderly patients' pathways. Future studies might help guiding triage and providing tools to homogenize the practice and avoid futile treatment in the ICU. ${ }^{7}$ In one hand, some physicians $(20 \%)$ consider that guidelines are of little help and that every patient should be assessed individually and not as a group. In the other hand, respondents working in ICUs located in countries with low health expenditure are in favor of ICU and hospital guidelines. Advance directive should be promoted for $97 \%$ of respondents. However, even after change in legislation in Germany, advance directive with living and therapeutic wills were available in $<10 \%$ of the cases. ${ }^{15}$ In the Ethicus study, performed in 17 European countries, the primary reason given by physicians for end of life decisions was the living will in only $1 \%$ of cases. ${ }^{16}$ In a prospective study involving patients aged 80 or more, it was shown that advance care planning was able to improve end of life care, patient and family satisfaction while reducing stress, anxiety and depression among surviving relatives. ${ }^{17}$

Seeking relatives' opinion if a patient is unable to communicate is not mandatory for $17 \%$ of the respondents. It suggests a paternalistic approach in some ICUs but there was no difference according to regions. Again, the organization is probably more ICU-centered than relying on general guidelines. In some countries, like France, it is mandatory since 
Table 4 Univariate comparison according to number of critical care beds by country (Fisher test).

\begin{tabular}{|c|c|c|c|c|}
\hline & & $\begin{array}{l}\text { High level }^{a} \\
N=31\end{array}$ & $\begin{array}{l}\text { Low Level } \\
N=124\end{array}$ & $P$-value \\
\hline \multirow{3}{*}{$\begin{array}{l}\text { There is clear } \\
\text { evidence that } \\
\text { ICU admission is } \\
\text { beneficial for } \\
\text { elderly ICU } \\
\text { patients at a } \\
\text { group level }\end{array}$} & Agree & $19(61)$ & $77(63)$ & \multirow[t]{3}{*}{0.89} \\
\hline & Disagree & $12(39)$ & $46(37)$ & \\
\hline & NA & 0 & 1 & \\
\hline \multirow{3}{*}{$\begin{array}{l}\text { Patients advance } \\
\text { directives should } \\
\text { be promoted at } \\
\text { any level in the } \\
\text { hospital }\end{array}$} & Agree & 31 (100) & $117(96)$ & \multirow[t]{3}{*}{0.25} \\
\hline & Disagree & $0(0)$ & $5(4)$ & \\
\hline & NA & 0 & 2 & \\
\hline \multirow{3}{*}{$\begin{array}{l}\text { If a patient is } \\
\text { unable to } \\
\text { communicate, } \\
\text { seeking for } \\
\text { relatives opinion } \\
\text { on behalf of the } \\
\text { elderly person is } \\
\text { mandatory }\end{array}$} & Agree & $27(87)$ & $100(81)$ & \multirow[t]{3}{*}{0.45} \\
\hline & Disagree & $4(13)$ & $23(19)$ & \\
\hline & NA & 0 & 1 & \\
\hline \multirow{3}{*}{$\begin{array}{l}\text { Written triage } \\
\text { guidelines must } \\
\text { be available at } \\
\text { the hospital level }\end{array}$} & Agree & $21(70)$ & $92(79)$ & \multirow[t]{6}{*}{0.28} \\
\hline & Disagree & 9 (30) & $24(21)$ & \\
\hline & NA & 1 & 8 & \\
\hline \multirow{3}{*}{$\begin{array}{l}\text { Written triage } \\
\text { guidelines must } \\
\text { be available at } \\
\text { the ICU level }\end{array}$} & Agree & $21(70)$ & $98(80)$ & \\
\hline & Disagree & $9(30)$ & $24(20)$ & \\
\hline & NA & 1 & 2 & \\
\hline \multirow{3}{*}{$\begin{array}{l}\text { Assessment of } \\
\text { frailty should be } \\
\text { mandatory when } \\
\text { deciding to admit } \\
\text { an elderly patient } \\
\text { in ICU }\end{array}$} & Agree & $28(90)$ & $113(93)$ & \multirow[t]{3}{*}{0.56} \\
\hline & Disagree & $3(10)$ & $8(7)$ & \\
\hline & NA & 0 & 3 & \\
\hline \multirow{2}{*}{$\begin{array}{l}\text { Early goal directed } \\
\text { rehabilitation } \\
\text { programs should } \\
\text { be promoted }\end{array}$} & Agree & 31 (100) & $120(97)$ & \multirow[t]{2}{*}{0.31} \\
\hline & Disagree & $0(0)$ & $4(3)$ & \\
\hline \multirow{3}{*}{$\begin{array}{l}\text { In case of } \\
\text { uncertainty } \\
\text { about the } \\
\text { condition, the } \\
\text { patient should be } \\
\text { admitted and } \\
\text { given an ICU trial }\end{array}$} & Agree & $28(93)$ & $113(92)$ & \multirow[t]{3}{*}{0.79} \\
\hline & Disagree & $2(7)$ & $10(8)$ & \\
\hline & NA & 1 & 1 & \\
\hline
\end{tabular}

2002 to seek for patients' representative opinion and the information must be available in the patient files. ${ }^{18}$ However, for patients able to
Table 4 (Continued)

\begin{tabular}{|c|c|c|c|c|}
\hline & & $\begin{array}{l}\text { High level }^{a} \\
N=31\end{array}$ & $\begin{array}{l}\text { Low Level } \\
N=124\end{array}$ & $P$-value \\
\hline \multirow{3}{*}{$\begin{array}{l}\text { Level of care } \\
\text { should be } \\
\text { systematically } \\
\text { and collectively } \\
\text { reassess at day } 2 \\
-3 \text { in the ICU ('in } \\
\text { ICU triage') }\end{array}$} & Agree & $28(93)$ & 112 (92) & 0.78 \\
\hline & Disagree & $2(7)$ & $10(8)$ & \\
\hline & NA & 1 & 2 & \\
\hline \multirow{3}{*}{$\begin{array}{l}\text { In particular in the } \\
\text { elderly patients, } \\
\text { less is more with } \\
\text { regards to } \\
\text { common ICU } \\
\text { procedures with } \\
\text { exception of } \\
\text { early mobilization } \\
\text { and training } \\
\text { activities }\end{array}$} & Agree & $22(71)$ & $93(76)$ & 0.60 \\
\hline & Disagree & $9(29)$ & $30(24)$ & \\
\hline & NA & 0 & 1 & \\
\hline \multirow{3}{*}{$\begin{array}{l}\text { The consultation } \\
\text { of a geriatrician } \\
\text { should be sought } \\
\text { whenever } \\
\text { possible }\end{array}$} & Agree & $20(67)$ & $81(68)$ & 0.93 \\
\hline & Disagree & $10(33)$ & 39 (32) & \\
\hline & NA & 1 & 4 & \\
\hline \multirow{3}{*}{$\begin{array}{l}\text { A geriatrician } \\
\text { should be a part } \\
\text { of the post-ICU } \\
\text { trail for survivors }\end{array}$} & Agree & $27(87)$ & $110(90)$ & 0.62 \\
\hline & Disagree & $4(13)$ & $12(10)$ & \\
\hline & NA & 0 & 2 & \\
\hline
\end{tabular}

${ }^{a}$ High: France; Czech Republic; Italy; Germany; Austria; Romania; Belgium.

response, their opinion was asked only in little more than $10 \%$ in a prospective observational study conducted in France ${ }^{19}$ illustrating discrepancies between reality, response to survey and regulation.

One quarter of respondents believed that level of care should be similar in elderly and younger patients suggesting that once admitted, there is no reason to treat elderly patients less actively that younger patients.

Elderly patients receive less aggressive treatment and duration of organ support tends to be shorter in comparison to younger patients..$^{20-23}$ This may suggest that in ICUs with liberal admission policy the treatment effect of elderly patients are reassessed early during the ICU stay. Thereby avoiding long-term ICU stays of elderly patients with a presumed poor prognosis because of lack of progress during the early 
Table 5 Univariate comparison according to health expenditure as a share of Gross Domestic product according to 2013 OCDE (Fisher test)

\begin{tabular}{|c|c|c|c|c|}
\hline & & $\begin{array}{l}\text { High level }^{\mathrm{a}} \\
N=98\end{array}$ & $\begin{array}{l}\text { Low Level } \\
N=57\end{array}$ & $P$-value \\
\hline \multirow{3}{*}{$\begin{array}{l}\text { There is clear evidence that ICU admission is beneficial for elderly ICU patients at a group } \\
\text { level }\end{array}$} & Agree & $55(57)$ & $41(72)$ & \multirow[t]{3}{*}{0.085} \\
\hline & Disagree & $42(43)$ & $16(28)$ & \\
\hline & NA & 1 & 0 & \\
\hline \multirow[t]{3}{*}{ Patients advance directives should be promoted at any level in the hospital } & Agree & $95(98)$ & $53(95)$ & \multirow[t]{3}{*}{0.36} \\
\hline & Disagree & $2(2)$ & $3(5)$ & \\
\hline & NA & 1 & 1 & \\
\hline \multirow{3}{*}{$\begin{array}{l}\text { If a patient is unable to communicate, seeking for relatives opinion on behalf of the elderly } \\
\text { person is mandatory }\end{array}$} & Agree & $78(80)$ & $53(95)$ & \multirow[t]{3}{*}{0.27} \\
\hline & Disagree & $20(20)$ & $7(12)$ & \\
\hline & NA & 0 & 1 & \\
\hline \multirow[t]{3}{*}{ Written triage guidelines must be available at the hospital level } & Agree & $67(71)$ & $46(88)$ & \multirow[t]{3}{*}{0.022} \\
\hline & Disagree & $27(29)$ & $6(12)$ & \\
\hline & NA & 4 & 5 & \\
\hline \multirow[t]{3}{*}{ Written triage guidelines must be available at the ICU level } & Agree & $70(71)$ & $49(91)$ & \multirow[t]{3}{*}{0.007} \\
\hline & Disagree & $28(29)$ & $5(9)$ & \\
\hline & NA & 0 & 3 & \\
\hline \multirow[t]{3}{*}{ Assessment of frailty should be mandatory when deciding to admit an elderly patient in ICU } & Agree & $88(92)$ & $53(95)$ & \multirow[t]{3}{*}{0.75} \\
\hline & Disagree & $8(8)$ & $3(5)$ & \\
\hline & NA & 2 & 1 & \\
\hline \multirow[t]{2}{*}{ Early goal directed rehabilitation programs should be promoted } & Agree & $94(96)$ & $57(100)$ & \multirow[t]{2}{*}{0.30} \\
\hline & Disagree & $4(4)$ & $0(0)$ & \\
\hline \multirow{3}{*}{$\begin{array}{l}\text { In case of uncertainty about the condition, the patient should be admitted and given an } \\
\text { ICU trial }\end{array}$} & Agree & $91(94)$ & $50(89)$ & \multirow[t]{3}{*}{0.36} \\
\hline & Disagree & $6(6)$ & $6(11)$ & \\
\hline & NA & 1 & 1 & \\
\hline \multirow{3}{*}{$\begin{array}{l}\text { Level of care should be systematically and collectively reassess at day 2-3 in the ICU ('in } \\
\text { ICU triage') }\end{array}$} & Agree & $88(93)$ & $52(91)$ & \multirow[t]{3}{*}{0.76} \\
\hline & Disagree & $7(7)$ & $5(9)$ & \\
\hline & NA & 3 & 0 & \\
\hline \multirow{3}{*}{$\begin{array}{l}\text { In particular in the elderly patients, less is more with regards to common ICU procedures } \\
\text { with exception of early mobilization and training activities }\end{array}$} & Agree & $67(68)$ & $48(86)$ & \multirow[t]{3}{*}{0.021} \\
\hline & Disagree & $31(32)$ & $8(14)$ & \\
\hline & NA & 0 & 1 & \\
\hline \multirow[t]{3}{*}{ The consultation of a geriatrician should be sought whenever possible } & Agree & $64(67)$ & $37(69)$ & \multirow[t]{3}{*}{0.86} \\
\hline & Disagree & $32(33)$ & $17(31)$ & \\
\hline & NA & 2 & 3 & \\
\hline \multirow[t]{3}{*}{ A geriatrician should be a part of the post-ICU trail for survivors } & Agree & $89(92)$ & $48(86)$ & \multirow[t]{3}{*}{0.28} \\
\hline & Disagree & $8(8)$ & $8(14)$ & \\
\hline & NA & 1 & 1 & \\
\hline
\end{tabular}

aHigh level: France; Denmark; Sweden; Netherlands; Germany; Austria; Belgium; Great Britain.

phase of an ICU stay. Some studies suggest that improvement of prognosis over time is related to more aggressive treatment. ${ }^{24}$ Health expenditure at the country level might also explain part of the responses with more respondents agreeing that 'less is more' for the elderly patients. The objective or perceived rationing is different among different countries. ${ }^{25}$

The poor overall prognosis could be related to poor quality of care after ICU discharge in wards without geriatric expertise. Several recent studies have documented that for post-operative patients, mainly after hip fracture, there was a benefit of being treated in a geriatric unit rather than in a surgical unit with reduced mortality and LOS. ${ }^{26,27}$ Treatment of patients in a geriatric unit after discharge from ICU could potentially improve the long-term outcome. However, only $46 \%$ strongly agrees that frailty should be assessed even though several studies have documented that frailty score had a major impact not so much on ICU stay characteristics but on 
hospital LOS, mortality, discharge location and long-term outcomes. ${ }^{7,28,29}$

Given the multifaceted health problem of elderly patients, the expertise of a geriatrician should be very beneficial but only $17.9 \%$ agree that a geriatric consultation should be sought whenever possible and $33.8 \%$ that a geriatrician should be part of the discharge process. Again, there is a lack of evidenced-based recommendation regarding the contribution of the geriatrician in the hospital trajectory of critically ill elderly patients.

Our study outlines the heterogeneity of responses and the discrepancies between responses and scientific evidence. In that perspective it emphasizes the absolute necessity to perform trials for this specific population. ${ }^{2,30}$

Our study has important limitations that need to be discussed.

First, we lack formal external and internal validity. The respondents are not representative of European ICU physicians and of ICUs. Although, most of them worked in general ICUs (either mixed, medical or surgical), are experienced physicians since they were coordinator for the VIP study and are interested in the field of research on elderly patients. Despite, this biased panel of responds with probably more physicians willing to treat octogenarians, we obtained variety of responses to the survey.

Second, this survey probed only the attitude by experienced ICU physicians and not by young doctors, nurses, patients or relatives. According to the type of decision, the contribution of other health professionals is different. Admission is usually decided by senior ICU physicians but the patient and next-of-kin might be involved. As a matter of fact, it has been shown that large discrepancy might exist between ICU physician proposal and patients' wishes. ${ }^{31}$ For level of care and discharge, the nurses are contributing to the decision. However, for discharge, there are neither recent guidelines $^{32}$ nor validated tools. ${ }^{33}$

Third, we did not explore in detail the longterm trajectory and did not discuss the readmission policy.

Fourth; we did not use case vignette methodology $^{34}$ to illustrate in simulated cases the consistency of the response. It is true that an extremely frail elderly patient with many comorbidities and a septic shock at admission ${ }^{35}$ will have a different chance of long-term survival than a very fit 80 -year-old that needs planned cardiac surgery. ICU physicians will have different opinions on admission for these patients. Such differences cannot be picked up by the survey and will partially explain the variance in answers. Physicians have different patients in mind when answering these questions.

Fifth, legal or judicial differences between countries and cultures influence the willingness to admit patients. If a physician is not allowed to refuse admission of a patient then this will influence his/her answer. In most of the participating countries the ICU physicians can decide to admit or refuse elderly patients. There was a marked variation in the rejection rate (from 5\% to $48 \%$ ) in the 11 different ICUs participating in the Eldicus study. ${ }^{4}$ The differences may be related to legislation, to religion and to local recommendations but does not seem to be influenced by ICU bed availability. Finally, we only questioned ICU physicians. As discussed earlier, triage is a multi-step, multidisciplinary, and collective decision. ${ }^{36-38}$ If emergency physicians are very restrictive in their referral policy then ICU physicians only get the best selection. This will color their opinions on the chances of such patients. In other words, a tendency to aggressively treat elderly patients on the ICU might be the result of a major selection prior to the ICU and vice versa.

\section{Conclusion}

Despite obvious limitations this is the first surveys on the attitudes of ICU physicians to care for very elderly critically ill patients. We have clearly shown that there is a considerable variation between ICUs and regions. The factors influencing these opinions and subsequent willingness to admit elderly patients need to be elucidated. A proposal for future research has recently been launched. ${ }^{2}$ Clearly, we need to provide more evidence to ICU and referring physicians to help them in the decision-making process of proposal, admission, discharge and level of care during the ICU stay. The lack of agreement among experienced ICU physicians for most of proposed statements emphasizes the 
necessity to conduct large scale studies for critically ill elderly patients. ${ }^{2}$

\section{Acknowledgements}

We thank all the VIP ICU coordinators who answered the survey and the Health Services and Outcome section of the European Society of Intensive Care Medicine.

\section{References}

1. Leblanc G, Boumendil A, Guidet B. Ten things to know about critically ill elderly patients. Intensive Care Med 2017; 43: 217-9.

2. Flaatten H, de Lange DW, Artigas A, Bin D, Moreno R, Christensen S, Joynt GM, Bagshaw SM, Sprung CL, Benoit D, Soares M, Guidet B. The status of ICM research and a future agenda for very elderly patients in the ICU. Intensive Care Med 2017; 43: 1319-28. https://doi.org/10.1007/s00134017-4718-z.

3. Laake JH, Dybwik K, Flaatten HK, Fonneland I-L, Kvåle R, Strand K. Impact of the post-World War II generation on intensive care needs in Norway. Acta Anaesthesiol Scand 2010; 54: 479-84.

4. Sprung CL, Artigas A, Kesecioglu J, Pezzi A, Wiis J, Pirracchio R, Baras M, Edbrooke DL, Pesenti A, Bakker J, Hargreaves C, Gurman G, Cohen SL, Lippert A, Payen D, Corbella D, Iapichino G. The Eldicus prospective, observational study of triage decision making in European intensive care units. Part II: intensive care benefit for the elderly. Crit Care Med 2012; 40: 132-8.

5. Boumendil A, Angus DC, Guitonneau AL, Menn AM, Ginsburg C, Takun K, Davido A, Masmoudi R, Doumenc B, Pateron D, Garrouste-Orgeas M, Somme D, Simon T, Aegerter P, Guidet B, ICE-CUB study group. Variability of intensive care admission decisions for the very elderly. PLoS One 2012; 7: e34387.

6. Garrouste-Orgeas M, Boumendil A, Pateron D, Aergerter P, Somme D, Simon T, Guidet B, ICECUB Group. Selection of ICU admission criteria for patients aged 80 years and over and compliance of emergency and ICU physicians with the selected criteria: an observational multicenter prospective study. Crit Care Med 2009; 37: 2919-28.

7. Flaatten H, De Lange D, Morandi A, Andersen F, Artigas A, Bertolini G, Cecconi M, Christensen S, Feraldi L, Fjölner J, Jung C, Marsh B, Moreno R,
Bollen Pinto B, Szczeklik W, Valentin A, Watson X, Zaferidis T, Guidet B. The impact of frailty on ICU and 30-day mortality and the level of care in very elderly patients ( $\geq 80$ years). Intensive Care Med 2017; 43: 4940-8.

8. Rhodes A, Ferdinande P, Flaatten H, Guidet B, Metnitz PG, Moreno RP. The variability of critical care beds numbers in Europe. Intensive Care Med 2012; 38: 1647-53.

9. Organisation for Economic Co-operation and Development: OECD. Health at a glance 2013: OECD indicators. Paris: OECD, 2013. https://doi. org/10.1787/health_glance-2013-en.

10. Guidet B, Leblanc G, Simon T, Woimant M, Quenot JP, Ganansia O, Maignan M, Yordanov Y, Delerme S, Doumenc B, Fartoukh M, Charestan P, Trognon P, Galichon B, Javaud N, Patzak A, Garrouste-Orgeas M, Thomas C, Azerad S, Pateron D, Boumendil A, on behalf of the ICE-CUB 2 study network. Effect of systematic intensive care unit triage on long-term mortality among critically ill elderly patients in France: a randomized clinical trial. JAMA 2017; 318: 1450-9.

11. Boumendil A, Somme D, Garrouste-Orgeas M, Guidet B. Should elderly patients be admitted to the intensive care unit? Intensive Care Med 2007; 33: 1252-62.

12. N'Guyen YL, Angus DA, Boumendil A, Guidet B. The challenge of admitting the very elderly to intensive care. Ann Intensive Care 2011; 1: 29.

13. Nielsson MS, Christiansen CF, Johansen MB, Rasmussen BS, Tønnesen E, Nørgaard M. Mortality in elderly ICU patients: a cohort study. Acta Anaesthesiol Scand 2014; 58: 19-26.

14. Boumendil A, Latouche A, Guidet B, ICE-CUB Study Group. On the benefit of intensive care for very old patients. Arch Intern Med 2011; 171: 1116-7.

15. Graw JA, Spies CD, Wernecke KD, Braun JP. Managing end of life decision making in intensive care medicine- A perspective from Charité Hospital, Germany. PLOS One 2012; 7: e46446.

16. Sprung CL, Woodcock T, Sjokvist P, Ricou B, Bulow HH, Lippert A, Maia P, Cohen S, Baras M, Hovilehto S, Ledoux D, Phelan D, Wennberg E, Schobersberger W. Reasons, considerations, difficulties and documentation of end-of-life decisions in European intensive care units: the ETHICUS Study. Intensive Care Med 2008; 34: 271-7.

17. Detering KM, Hancock AD, Reade MC, Silvester W. The impact of advance care planning on end of life care in elderly patients: randomized controlled trial. BMJ 2010; 340: c1345. 
18. LOI no 2002-303 du 4 mars 2002 relative aux droits des malades et à la qualité du système de santé. Available at: https://www.legifrance.gouv.fr/eli/loi/ 2002/3/4/MESX01 (accessed 16 August 2017).

19. Le Guen J, Boumendil A, Guidet B, Corval A, Saint-Jean O, Somme D. Are elderly patients' sought before admission to an intensive care unit? Results of the ICE-CUB study. Age Ageing 2016; 45: 303-9.

20. van Delden JJ, Vrakking AM, van der Heide A, van der Maas PJ. Medical decision making in scarcity situations. J Med Ethics 2004; 30: 20711.

21. Brockmann H. Why is less money spent on health care for the elderly than for the rest of the population? Health care rationing in German hospitals. Soc Sci Med 2002; 55: 593-608.

22. Boumendil A, Aegerter P, Guidet B. Treatment intensity and outcome of patients aged 80 and older in intensive care units: a multicenter matchedcohort study. J Am Geriatr Soc 2005; 53: 88-93.

23. Andersen FH, Kvåle R. Do elderly intensive care unit patients receive less intensive care treatment and have higher mortality? Acta Anaesthesiol Scand 2012; 56: 1298-305.

24. Lerolle N, Trinquart L, Bornstain C, Tadié JM, Imbert A, Diehl JL, Fagon JY, Guérot E. Increased intensity of treatment and decreased mortality in elderly patients in an intensive care unit over a decade. Crit Care Med 2010; 38: 59-64.

25. Evans T, Nava S, Vazquez Mata G, Guidet B, Estenssoro E, Fowler R, White D, Manthous C. Critical care rationing: international comparisons. Chest 2011; 140: 1618-24.

26. Boddaert J, Cohen-Bittan J, Khiami F, Le Manach Y, Raux M, Beinis JY, Verny M, Riou B. Postoperative admission to a dedicated geriatric unit decreases mortality in elderly patients with hip fracture. PLoS One 2014; 15: e83795.

27. Kristensen PK, Thillemann TM, Søballe K, Johnsen SP. Can improved quality of care explain the success of orthogeriatric units? A population-based cohort study Age Ageing 2016; 45: 66-71.

28. Bagshaw SM, Stelfox HT, McDermid RC, Rolfson DB, Tsuyuki RT, Baig N, Artiuch B, Ibrahim Q, Stollery DE, Rokosh E, Majumdar SR. Association between frailty and short- and long-term outcomes among critically ill patients: a multicentre prospective cohort study. CMAJ 2014; 186: E95-102.

29. Bagshaw SM, Stelfox HT, Johnson JA, McDermid RC, Rolfson DB, Tsuyuki RT, Ibrahim Q, Majumdar SR. Long-term association between frailty and health-related quality of life among survivors of critical illness: a prospective multicenter cohort study. Crit Care Med 2015; 43: 973-82.

30. Boumendil A, Woimant M, Quenot JP, Rooryck FX, Makhlouf F, Yordanov Y, Delerme S, Takun K, Ray P, Kouka MC, Poly C, Garrouste M, Thomas C, Simon T, Azerad S, Leblanc G, Pateron D, Guidet $\mathrm{B}$, on behalf of the ICE-CUB 2 study network. Designing and conducting a cluster-randomized trial of ICU admission for the elderly patients: the ICE-CUB 2 study. Ann Intensive Care 2016; 6: 74.

31. Philippart F, Vesin A, Bruel C, Kpodji A, Durand-Gasselin B, Garçon P, Levy-Soussan M, Jagot JL, Calvo-Verjat N, Timsit JF, Misset B, Garrouste-Orgeas M. The ETHICA study (part I): elderly's thoughts about intensive care unit admission for life-sustaining treatments. Intensive Care Med 2013; 39: 1565-73.

32. Nasraway SA, Cohen IL, Dennis RC, Howenstein MA, Nikas DK, Warren J, Wedel SK. Guidelines on admission and discharge for adult intermediate care units. American College of Critical Care Medicine of the Society of Critical Care Medicine. Crit Care Med 1998; 26: 607-10.

33. Heidegger CP, Treggiari MM, Romand JA, Swiss ICU Network. A nationwide survey of intensive care unit discharge practices. Intensive Care Med 2005; 31: 1676-82.

34. N'Guyen YL, Perrodeau E, Guidet B, Trinquart L, Mercat A, Jolliet P, Ravaud P, Richard JC, Brochard L. Mechanical ventilation practice heterogeneity. A multi-center case-vignette study. Ann Intensive Care 2014; 4: 2.

35. Biston P, Aldecoa C, Devriendt J, Madl C, Chochrad D, Vincent JL, De Backer D. Outcome of elderly patients with circulatory failure. Intensive Care Med 2014; 40: 50-6.

36. Garrouste-Orgeas M, Montuclard L, Timsit JF, Misset B, Christias M, Carlet J. Triaging patients to the ICU: a pilot study of factors influencing admission decisions and patient outcomes. Intensive Care Med 2003; 29: 774-81.

37. Garrouste-Orgeas M, Montuclard L, Timsit JF, Reignier J, Desmettre T, Karoubi P, Moreau D, Montesino L, Duguet A, Boussat S, Ede C, Monseau Y, Paule T, Misset B, Carlet J, French ADMISSIONREA Study Group. Predictors of intensive care unit refusal in French intensive care units: a multiple-center study. Crit Care Med 2005; 33: $750-5$.

38. Joynt GM, Gomersall CD, Tan P, Lee A, Cheng CA, Wong EL. Prospective evaluation of patients refused admission to an intensive care unit: triage, futility and outcome. Intensive Care Med 2001; 27: 1459-65. 


\section{Supporting Information}

Additional Supporting Information may be found in the online version of this article at the publisher's web-site:

Table S1. Characteristics of participating European countries: Health expenditure, number of
ICU beds and percentage of patients older than 80 years.

Data S1. ESM: key messages of Verbatim. 